\title{
Integrative and instrumental but low investment: The English learning motivation of Indonesian senior high school students
}

\author{
Ahmad Bukhori Muslim*, Fuad Abdul Hamied, and Didi Sukyadi \\ Department of English Education, Faculty of Language and Literature Education, Universitas Pendidikan Indonesia, \\ Jalan Dr. Setiabudhi No. 229, Bandung, West Java, Indonesia
}

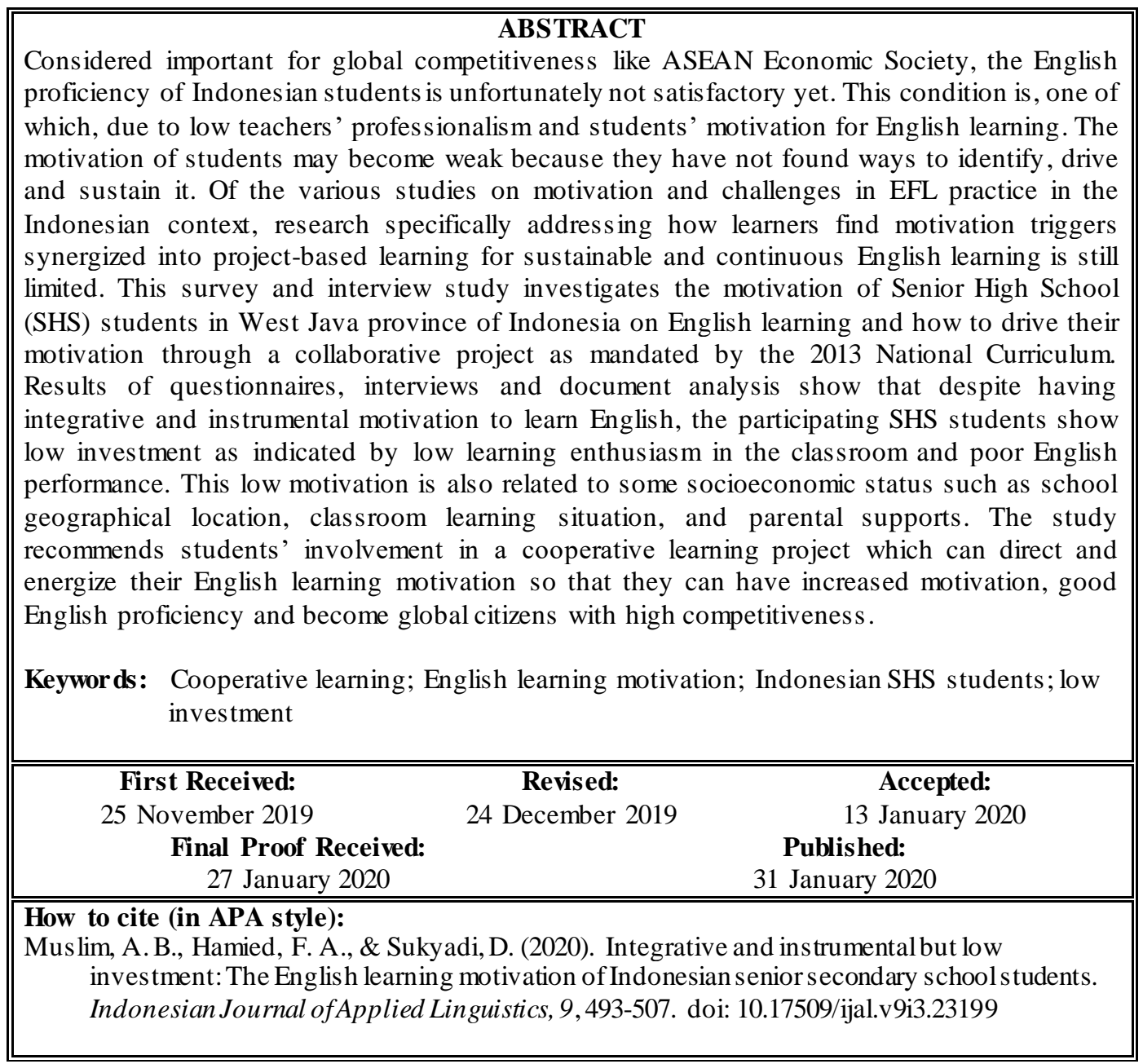

\section{INTRODUCTION}

One key aspect of human development in the Indonesian context is good English proficiency. For people in non-English speaking countries, like Indonesian youth, this language competence paves ways for the global world (Sayer, 2018). This competence should serve as a positive capital for demography bonus Indonesia is predicted to have in 2045 so that its citizens can have high global competitiveness like in ASEAN economic society. Nevertheless, evidence shows that the practice of English language teaching in Indonesia still faces challenges and constraints (Lamb 2004, 2007,
2013; Marcelino, 2008; Musthafa, 2010; Yulia, 2013) so that students' English proficiency, as the outcome, is not satisfactory yet. This is due to many reasons, one of which is low teachers' professionalism at all levels, from primary to secondary, far below that of their counterparts in other ASEAN countries such as Singapore, Malaysia, Vietnam, Thailand and the Philippine (Waterworth, 2016). In fact, as many scholars have suggested, competent English teachers may compensate for other unsatisfactory learning elements such as facilities, learning materials, and teaching methods.

\footnotetext{
* Corresponding Author

Email: abukhmuslim@upi.edu
} 
In addition to teachers' low professionalism, another challenge in improving students' English proficiency in the Indonesian context is low learning motivation (Lamb, 2007; Yulia, 2013; Supriyanti, 2012). Many factors contribute to students' low motivation, including ineffective learning methods, less supporting facilities and less innovative learning materials. Students may also have weak motivation because they have not found ways to trigger motivation, like building awareness on the importance of English language skills in developing the human index. In this line, students need to receive guidance and support on how to improve their learning motivation so that they can improve their English language competence leading to their more increased global competitiveness.

Based on some challenges Indonesians who learn English have been facing, this study seeks to investigate the motivation of SHS from the low socio-economic background and how they may invest in learning English as indicated by questionnaires and informal interviews with teachers. The questionnaire includes students' personal motivation (intended efforts to learn, ideal and ought-to selves) and social aspects of motivation (international posture, influences of teachers, peers, and parents), whereas interviews confirm students' English achievement and their commitment to English learning.

\section{Motivation and English language learning}

Motivation is an important aspect of successfulteaching and learning. It is a strong trigger for more independent and autonomous learning. A famous linguist, Chomsky (as cited in Amold, 2000) even pointed out the main purpose of teaching is, in fact, 'making the students feel interested in the material' (p. 13). For this, motivation has become an integrated and holistic ideology of learning a foreign language (Harvey, 2017), including the English language. Considering the importance of motivation in learning all subjects, including English, Schunk, Pintrich, and Meece (2008) believe that motivation can 'instigate and sustain' the learning process (p. 4). This psychological support serves as the reasons which 'underlie the behaviours or why people do what they do (Guay et al., 2010, p. 712). In English learning, motivation instigates strong willingness in students like those of SHS in Indonesia to learn and maintain eagerness to study so that they can achieve the expected English competencies.

In general, learning motivation is of various types. Some learners show instrumental motivation when they enjoy the process of language learning for the sake of English learning, such as good school grade or secure future career. Meanwhile, other students have the integrative motivation, believing that they learn English so that they can communicate, socialize and use English with its native speakers. Others have more negative or positive motivation towards English learning (CarrióPastor \& Mestre, 2014; Iwaniec, 2014; Khajehpour \& Ghazvinia, 2011) or external and internal motivation of learning foreign languages (Zubairi \& Sarudin, 2009).
Of these types, integrative motivation seems to strongly influence the success of language learning (Crookes \& Schimdt, 1991; Ellis, 1994; Taylor, Meynard \& Rheault, 1977). In the Indonesian context, Lamb (2004, 2007, 2013) found that many students have shown both instrumental and integrative motivation. They believe that mastery of English language is important in this global era so that students can play active and significant roles in their future global engagement. In addition, motivation is also strongly influenced by socioeconomic status (SES). For instance, researching the motivation of language learning among Chilean English learners, Kormos and Kiddle (2013) found that students of low and medium SES tend to have low motivation, self-regulation, and learning autonomy compared to those of high and medium SES.

Many scholars in second or foreign language learning have focused their attention on the importance of motivation in English learning. Dörnyei (1994), for example, classifies motivation into three main aspects; language, learner and learning situation. The language aspect relates to two main components; motivation as instrumental and integrative. The aspect of learner relates to some elements such as need for achievement, self-confidence, language use anxiety, perceived L2 competence, causal attributions, and self-efficacy. Meanwhile, learning situation includes three elements; course, teacher, and group. The first is in the form of course-specific motivation which deals with learners' interests, relevance, expectancy, and satisfaction ( $p$. 277). The second component focuses on how teachers present and organize their learning process to attract students' attention and interests. The last aspect, groupspecific motivation relates to group objectives, norm and reward system, group unity and classroom purposes.

In addition, another linguist, Norton (2000, 2013) also relates motivation to investment in language learning. When learners, including those of English, feel instrumentally or integratively motivated, they will usually invest their energy, time, and even finance to learn the language. This investment is made because learners believe that learning the language has been part of their identity. In line with Dörnyei's (1994) groupspecific motivation (p. 277), Norton (2013) also argues that this individual investment can relate individual learners to the wider world as their social identification (p. 3). In relation to this study, English learners at junior and secondary schools in Indonesia who will participate in the current study may form certain groups as their social identity in which they can invest and support each other to achieve their goal of learning English as part of their social identity. They may also be willing to spend their time and energy to achieve the desired English proficiency necessary for the human index development of the country.

\section{Cooperative Learning (CL) as social engagement}

As language learning is a social process, to achieve a more successful result, language learning should 
become a means of social engagement. Most English learners, particularly young people like students of secondary school, are usually less autonomous and extrinsically more motivated by other people. Along with the task of personal development by Jean Piaget and Vygotsky's social constructivism, young people are mostly unaware of what they have to do and how to do certain activities on their own so that they need external motivation and stimulation from their environment in a cooperative learning (Kagan, 1994; Richards \& Rodgers, 2001). In line with the concept of learning autonomy, Cooperative Learning (CL) provides a larger room for learners to have more dominant roles. In the teaching of English, CL is believed to be able to improve the use of the target language, communication skills, self-development and learner autonomy (Çelik, Aytin, \& Bayram, 2013; Iwaniec, 2014; Zhou, 2012). In this information era, the use of communication technology in cooperative learning enables learners to be more motivated to learn English (Carrió-Pastor \& Skorczynska, 2015).

As a model, CL has certain measurable principles. Johnson and Johnson (1994) describe five main principles of cooperative learning which include positive interdependence, face-to-face interaction, individual accountability, group processing, and social skills. Positive interdependence requires each of the group members to be held responsible for what has been assigned because it will contribute to the group success. Face-to-face interaction enables group members to work within certain physical closeness with others so that they can practice the language skills they have learned. Individual accountability grows members' selfconfidence as each member is considered to have the ability to complete the assigned tasks. Group processing allows each member of the group to see the strength and weakness of the other members through a feedback program. Finally, cooperative learning also develops the social skills of the group members, which include leadership, conflict management, dan decision making. These principles of communal learning can have a positive influence on the development of language skills of English learners in the context of Indonesia whom this study focuses on.

Furthermore, the success of CL depends on some supporting structures. Olsen and Kagan (1992) argue that CL will work more effectively when supported by five main structures; the goals, rewards, students' roles, materials, and rules. Goal serves as the main objective of the group project, like drama performance for English learners. A reward is provided more for a group than an individual, although each participant is also given a certain role. In a drama performance, for example, a reward is equally given to those on the stage and at the back stage. Learning materials should also be adjusted to the group's need. The last is the rules that should enable the achievement of group objectives or purposes. In line with this main structure, Dörnyei (1997) believes that the principles of CL developed by Olsen and Kagan (1992) can develop many types of group structure, including peer relationship and learning rules that can become the basis for improving students' motivation to finish their assigned tasks (p. 491).

Various studies have been conducted on the importance of external or social motivation in English language learning as part of CL. For example, among African English learners, Libyan EFL learners are negatively affected by their negative teacher's classroom behaviours (Alhodiry, 2016). In the context of Iran, Mahmoodi, Kalantari and Ghaslani (2014) found a significant relationship between motivation and students' self-regulated learning. Students who have high integrative and instrumental motivation sustain learning on their own but no significant relationship with English learning achievement. They argue that other factors such as educational system, learning material, and teacher may have affected their learning achievement. Supporting this, another study by Vatankhah and Tanbakooei (2014) shows social supports from parents, siblings and EFL teachers significantly influence the intrinsic and extrinsic motivation of Iranian English learners. In relation to learning achievement, Zhou (2012) found that CL can raise students' motivational variables such as 'achievement and positive social outcomes' (p. 1322) among Chinese EFL learners. Meanwhile, in his study among Japanese EFL learners, Tanaka (2017) found that demotivated peers have a negative influence on English learning. Some similar studies have also been carried out in Indonesian context (Lamb, 2004, 2007, 2013; Marcelino, 2008; Musthafa, 2010). These studies address some principal challenges in English learning practices among Indonesian students which are caused by many factors, including low teachers' professionalism, limited supporting facilities and students' low motivation.

\section{The 2013 English Curriculum and Directed Motivational Currents (DMC)}

Based on the most recently applied 2013 National Curriculum in Indonesia, the English learning for junior and senior high school students is Genre-Based Approach (Ministry of Education and Culture, 2013). The teaching of English focuses on the function and characteristics of text-types within project work as part of CL. In relation to learning autonomy, Curriculum 2013 provides teachers with the flexibility to adjust their learning materials relevant to their students' needs and cultural backgrounds. Not only can this accommodation to local culture support students' learning autonomy but also their motivation. For example, Indonesian students of senior high school are more interested in learning local narrative texts which are derived from their cultural backgrounds such as Danau Toba, Sangkuriang and Joko Tingkir than those of English cultures such as Snow White, Sleeping Beauty and The Goldilock (Muslim, Nafisah, \& Damayanti, 2009). These local stories can also improve students' sense of national identity of being Indonesians (Muslim, 2017) which is necessary to support multiculturalism. Although written 
in English, students find it easier to understand these local legend narratives, which become the learning materials of English as they are familiar with the contents of the narratives.

Based on this account of social engagement and learning autonomy, the use of CL in English teaching is expected to give a more positive motivation if English learners receive sufficient guidance on how to direct and synergize their learning objectives in a real activity of Group-Directed Motivational Currents or G-DMC (Dörnyei, Henry, \& Muir, 2016). These scholars argue that the strength of DMC compared to other motivation theories is its ability to 'direct and energize' the power or currents, like waves in the sea, of students' motivation to achieve their goals, orientation, needs, and aspirations' (p. xi). Furthermore, in line with the project frameworks developed by Beckett and Slater (2005), GDMC combines 'the language, content, and skill development' organized in a project which includes six main structures; the goal, a planning graph, a project diary, a project proposal, portfolio, as well as regular progress check and feedback. In addition, the concept of sharing and caring in cooperative learning backed by sufficient teacher's supports can improve students' learning motivation (Stapa, Ibrahim, \& Yusoff, 2015). The main principles and structures of cooperative learning and Direct Motivational Currents (DMC) become the guidance in identifying and improving the motivation of SHS participating in this study.

\section{METHOD}

This survey and interview study employs a mixed method (Creswell, 2014; Hamied, 2017). Quantitative data were obtained from questionnaires adapted from Lamb (2004, 2007), and analysed by both descriptive and inferential statistic to identify students' language learning motivation and the influence of SES in improving English learning motivation. Meanwhile, obtained from document analysis (students' achievement) and teachers interviews, qualitative data were analysed on a thematic basis. The triangulation of these data serves as the basis to examine students' language learning motivation which becomes the reference in developing G-DMC model through a project-based approach.

\section{Participants}

Questionnaires were administered to about 450 students of senior high schools (public and private or religionbased), from five different cities across West Java province (Bandung, Sukabumi, Kuningan, Subang, dan Garut). Each city is represented by three senior high schools; 2 SMA (general) and 1 SMK (vocational) or MA (Religion-affiliated). For each school, students of years 10,11 and 12 were selected, 10 students from each class. Meanwhile, data of interviews and documents of students' achievement were derived from
15 teachers of senior high schools, who are the teachers of the participating students.

\section{Instruments}

Data in this study were derived from three instruments: students' questionnaires, teachers' interviews, and document of students' marks. Questionnaires of Likert scale (1-6) identify information about demography, constructs of an individual or personal motivation which include efforts made for English learning, ideal and ought-to selves, international posture, instrumentality, and social influences of motivation (peers, teachers, and parents). Details of each personal and social constructs can be seen in Appendices 1 and 2.

Furthermore, to complete information about motivation the questionnaires cannot reveal, interviews were administered to teachers of the participating students whereas students' marks were used to confirm their commitment for language learning. Meanwhile, statements for teachers include efforts they have made to synergize and improve students' motivation as well as the difficulties and challenges in directing and synergizing their English learning motivation (Appendix 3).

\section{FINDINGS}

In this study, findings include results of questionnaires and interviews with teachers. They cover personal and social aspects of motivation, including socio-economic status. The result of questionnaires was analyzed by descriptive and correlational statistics as follows.

\section{Personal or individual motivation}

Adapted from Lamb (2004, 2007), the questionnaire used in this study is divided into some constructs such as intended efforts, ideal and ought-to selves, international posture and instrumentality, social influence (family, teacher and peer), learning experience at both inside and outside schools and language anxiety. Besides, the questionnaire also includes some aspects of SES of the participating students, which include school geographical location, parental education, family English proficiency, and students' future jobs or professions.

As many as 445 , out of 450 expected, of SHS students from five different West Java cities have completed the questionnaires written in Likert scale of 1-6 (Strongly Disagree-Strongly Agree). For more convenient reading and easier comprehension, the result of the questionnaire is divided into three parts. The first part focuses on personal or individual aspects (intended efforts, ought-to and ideal selves, international posture and instrumentality), the second part focuses on social aspects (family, teacher, peer, school and non-school learning experiences and language anxiety), and the last section explores students' SES. To provide a more comprehensive understanding, the overall results of the questionnaire on personal aspects of motivation are described in Table 1 . 
Table 1. Personal aspects of English learning motivation

\begin{tabular}{|c|c|c|c|c|}
\hline & $\mathbf{N}$ & Minimum & Maximum & Mean \\
\hline \multicolumn{5}{|l|}{ Intended efforts } \\
\hline Statement 1 & 445 & 1.00 & 6.00 & 4.9124 \\
\hline Statement 2 & 446 & 1.00 & 6.00 & 4.0224 \\
\hline Statement 3 & 447 & 0.00 & 6.00 & 4.8389 \\
\hline Statement 4 & 446 & 0.00 & 6.00 & 4.0493 \\
\hline Average & & & & 4.0493 \\
\hline \multicolumn{5}{|l|}{ Ideal self } \\
\hline Statement 5 & 446 & 1.00 & 6.00 & 4.9955 \\
\hline Statement 6 & 447 & 1,00 & 6.00 & 4.5056 \\
\hline Statement 7 & 446 & 1.00 & 6.00 & 5.3767 \\
\hline Statement 8 & 445 & 0.00 & 6.00 & 5.3146 \\
\hline Statement 9 & 447 & 1.00 & 6.00 & 4.6040 \\
\hline Statement 10 & 447 & 1.00 & 6.00 & 5.3221 \\
\hline Statement 11 & 447 & 1.00 & 6.00 & 5.3714 \\
\hline Average & & & & 5.0428 \\
\hline \multicolumn{5}{|l|}{ Ought to self } \\
\hline Statement 12 & 446 & 1.00 & 6.00 & 4.5807 \\
\hline Statement 13 & 446 & 1.00 & 6.00 & 4.7534 \\
\hline Statement 14 & 447 & 1.00 & 6.00 & 4.6644 \\
\hline Statement 15 & 446 & 1.00 & 6.00 & 4.3587 \\
\hline Statement 16 & 443 & 0.00 & 6.00 & 2.7472 \\
\hline Statement 17 & 446 & 1.00 & 6.00 & 3.2780 \\
\hline Average & & & & 4.0500 \\
\hline \multicolumn{5}{|l|}{ International posture } \\
\hline Statement 18 & 447 & 1.00 & 6.00 & 5.0805 \\
\hline Statement 19 & 447 & 1.00 & 6.00 & 5.3132 \\
\hline Statement 20 & 445 & 1.00 & 6.00 & 5.1371 \\
\hline Statement 21 & 447 & 1.00 & 6.00 & 4.8814 \\
\hline Statement 22 & 446 & 0.00 & 6.00 & 4.5202 \\
\hline Average & & & & 4.9800 \\
\hline \multicolumn{5}{|l|}{ Instrumentality } \\
\hline Statement 23 & 447 & 1.00 & 6.00 & 4.4720 \\
\hline Statement 24 & 445 & 1.00 & 6.00 & 5.0157 \\
\hline Statement 25 & 445 & 1.00 & 6.00 & 5.0472 \\
\hline Statement 26 & 446 & 1.00 & 6.00 & 5.0650 \\
\hline Average & & & & 4.9000 \\
\hline Valid N (listwise) & 428 & & Average & 4.6044 \\
\hline
\end{tabular}

The Likert scale (1-6 scales) in this study is classified into two categories; negative (1-3) and positive (3-6). This positive category is then classified into three levels of motivation; low (4), medium (5) and strong (6). Based on this table, all participating students tend to have an average score of low to medium motivation as shown by personal and social aspects (4-5 in Likert scale). As Table 1 above shows, the average of intended efforts in English learning is 4.00 (low), the ideal self is 4.50 (low), the ought-to self is also low 4.00 (medium), international posture is slightly higher 4.50 (low), and instrumentality 4.75 (low).

Of these figures, however, some aspects have scores above 4 (four) in three constructs; ideal self (statements 7,8, 10 and 11), international posture (statements 18-20) and instrumentality (statements 2426). As for ideal self, most students highly agree that they have good English language skills, be able to effectively communicate with people from overseas. For international posture, most participating students believe that they want to learn English to be able to communicate with international people. Meanwhile, students instrumentally believe that English is necessary for their future careers, including university enrollment.

\section{Social motivation}

The second part of the questionnaire explores the social aspects of motivation which includes family, teacher, peer, classroom and non-classroom learning experience, and language anxiety. For a more thorough comprehension, the overall results of the questionnaire on social aspects of motivation are described in Table 2. Furthermore, based on Table 2, social aspects of motivation also show a similar level of motivation. The level of family influence is 4.25 (medium), teachers' influence is 4.67 (medium), peers' influence is lower (4.00), learning experience at school (4.00), outside school (4.25) higher than school, and language anxiety 
(4.00). Of these figures, however, some aspects have scores above 5.00 (five) from three aspects (family, teachers, and out of school). As open-ended questionnaires have indicated, most students believe that family strongly supports them to learn English well, teachers have a strong role and motivate to help English learning. Meanwhile, they like learning English outside school through song, films, and magazines. In general, as the table shows, students have low to medium levels of motivation (4-5), and no single aspect shows the high or maximum level of motivation (6.00 or strongly agree).

Table 2. Social aspects of English learning motivation

\begin{tabular}{|c|c|c|c|c|}
\hline & $\mathrm{N}$ & Minimum & Maximum & Mean \\
\hline \multicolumn{5}{|l|}{ Family influence } \\
\hline Statement 27 & 445 & 1.00 & 6.00 & 5.0135 \\
\hline Statement 28 & 444 & 1.00 & 6.00 & 3.8063 \\
\hline Statement 29 & 447 & 1.00 & 6.00 & 5.0358 \\
\hline Statement 30 & 447 & 1.00 & 6.00 & 4.5973 \\
\hline Average & & & & 4.5973 \\
\hline \multicolumn{5}{|c|}{ Teachers' influence } \\
\hline Statement 31 & 447 & 1.00 & 6.00 & 5.4295 \\
\hline Statement 32 & 447 & 1.00 & 6.00 & 5.1409 \\
\hline Statement 33 & 447 & 1.00 & 6.00 & 4.5324 \\
\hline Average & & & & 5.0342 \\
\hline \multicolumn{5}{|l|}{ Peer's influence } \\
\hline Statement 34 & 447 & 1.00 & 6.00 & 4.4519 \\
\hline Statement 35 & 445 & 1.00 & 6.00 & 4.4292 \\
\hline Statement 36 & 434 & 0.00 & 6.00 & 3.3548 \\
\hline Statement 37 & 445 & 0.00 & 6.00 & 4.2764 \\
\hline Statement 38 & 447 & 1.00 & 6.00 & 4.6555 \\
\hline Average & & & & 4.2335 \\
\hline \multicolumn{5}{|c|}{$\begin{array}{l}\text { Learning experience at } \\
\text { school }\end{array}$} \\
\hline Statement 39 & 447 & 1.00 & 6.00 & 4.4877 \\
\hline Statement 40 & 446 & 1.00 & 6.00 & 2.8587 \\
\hline Statement 41 & 446 & 1.00 & 6.00 & 4.4058 \\
\hline Statement 42 & 446 & 1.00 & 6.00 & 4.6928 \\
\hline Average & & & & 4.1112 \\
\hline \multicolumn{5}{|c|}{$\begin{array}{l}\text { Learning experience } \\
\text { outside school }\end{array}$} \\
\hline Statement 43 & 447 & 1.00 & 6.00 & 4.4407 \\
\hline Statement 44 & 447 & 1.00 & 6.00 & 5.0022 \\
\hline Statement 45 & 446 & 1.00 & 6.00 & 4.6883 \\
\hline Statement 46 & 447 & 0.00 & 6.00 & 4.0738 \\
\hline Average & & & & 4.5512 \\
\hline \multicolumn{5}{|l|}{ Language anxiety } \\
\hline Statement 47 & 447 & 1.00 & 6.00 & 4.5973 \\
\hline Statement 48 & 447 & 1.00 & 6.00 & 4.0179 \\
\hline Statement 49 & 446 & 1.00 & 6.00 & 4.4709 \\
\hline Statement 50 & 447 & 1.00 & 6.00 & 4.2394 \\
\hline Average & & & & 4.3313 \\
\hline Valid N (listwise) & 424 & & Average & 4.4764 \\
\hline
\end{tabular}

\section{Socio-economic status of participants}

In addition to exploring different constructs of personal and social motivation, the study also explores the SES of the participants, which may have an influence on their motivation. This aspect includes gender, school location, parents' educational background, English proficiency and occupations, English courses taken, computer skill learned, and future dream job or profession. Each of these aspects is described below.

As for gender, most of the participants $(62.9 \%)$ are female, and only $37.1 \%$ are male. Meanwhile, the majority of the schools in which the participants study is located in villages $(42.7 \%)$, followed by a small city (29.8\%) and big city (24.4\%). In terms of parental educational background, most students' parents only finished Senior Secondary School (30.0\%), followed by Primary School (25.7\%), Tertiary Education (21.0\%), and Junior Secondary School (18.3\%), whereas fathers have higher education than mothers. Furthermore, not many family members of the students have good English proficiency. Fathers who have taken an English course is only $19.9 \%$, and mothers with only 14.1. Fortunately, siblings have a higher proportion of 
English course $(32.9 \%)$, uncle or aunt $(17.9 \%)$, cousin (16.3) and others only $7.6 \%$.

Next, regarding parental occupation, fathers and mothers have different jobs. Most fathers work in private sectors such as businessman (46.5\%) followed by labours or workers (15.4\%), civil servants (11.4\%), and farmers $(6.7 \%)$ whereas another job has $7.8 \%$. As for the mother's occupation, most mothers have casual jobs $(73.8 \%)$, followed by a businessman $(8.9 \%)$, civil servants $(4.9 \%)$, and professionals $(4.0 \%)$. In addition, some students (37.1\%) have taken English courses, and most of them have good computer skill (70.9\%).

Finally, the participants have different future dream careers. A large number of them $(12.8 \%)$ want to be medical doctors, followed by teacher (10.5\%), businessman (9.4\%), architect (4.9\%), policeman and woman $(5.2 \%)$, lecturer and ambassador each (1.8\%). However, the majority of the participating students are still not sure about their future careers (13.0\%).

\section{Correlational analysis of motivational aspects}

In addition to descriptive analysis, the study also correlates motivational aspects of the participants to their SES. The inferential analysis relates motivation to gender, school location, parental education, family English skill, computer skill, and future or dream careers.

The first is a correlation between students' motivation and gender, as described in Table 3.

This table shows a significant correlation between students' intended efforts in learning English and gender (0.139). The table shows that gender strongly correlates with students' willingness to learn English very hard $(\mathrm{p}=.003)$ and doing their best in learning English $(p=.005)$. However, both male and female students have a low level of intended efforts in learning English.

The second is a correlation between motivation and school location, as shown in Table 4 below.

Table 3. Correlation between students' intended efforts (motivation) and gender

\begin{tabular}{|c|c|c|c|c|c|}
\hline & & Studying hard & Spending time & Doing best & Gender \\
\hline \multirow{3}{*}{$\begin{array}{l}\text { Studying English } \\
\text { very hard }\end{array}$} & Pearson Correlation & 1 & $.527^{* *}$ & $.489^{* *}$ & $.139^{* *}$ \\
\hline & Sig. (2-tailed) & & .000 & .000 & .003 \\
\hline & $\mathrm{N}$ & 445 & 444 & 445 & 445 \\
\hline \multirow{3}{*}{$\begin{array}{l}\text { Spending time for } \\
\text { studying English }\end{array}$} & Pearson Correlation & $.527^{* *}$ & 1 & $.392^{* *}$ & $.195^{* *}$ \\
\hline & Sig. (2-tailed) & .000 & & .000 & .000 \\
\hline & $\mathrm{N}$ & 444 & 446 & 446 & 446 \\
\hline \multirow{3}{*}{$\begin{array}{l}\text { Doing best in } \\
\text { studying English }\end{array}$} & Pearson Correlation & $.489^{* *}$ & $.392^{* *}$ & 1 & $.133^{* *}$ \\
\hline & Sig. (2-tailed) & .000 & .000 & & .005 \\
\hline & $\mathrm{N}$ & 445 & 446 & 447 & 447 \\
\hline \multirow[t]{3}{*}{ Gender } & Pearson Correlation & $.139^{* *}$ & $.195^{\text {** }}$ & $.133^{* *}$ & 1 \\
\hline & Sig. (2-tailed) & .003 & .000 & .005 & \\
\hline & $\mathrm{N}$ & 445 & 446 & 447 & 447 \\
\hline
\end{tabular}

**. Correlation is significant at the 0.01 level (2-tailed).

Table 4. Correlation between motivation and school location

\begin{tabular}{|c|c|c|c|c|c|}
\hline & & Study ing hard & Spending time & Doing best & School Location \\
\hline \multirow[t]{3}{*}{ Studying English very hard } & Pearson Correlation & 1 & $.527^{* *}$ & $.489^{* *}$ & $-.103^{*}$ \\
\hline & Sig. (2-tailed) & &, 000 &, 000 & 032 \\
\hline & $\mathrm{N}$ & 445 & 444 & 445 & 434 \\
\hline \multirow[t]{3}{*}{ Spending time for study ing English } & Pearson Correlation & $.527^{* *}$ & 1 & $.392^{* *}$ & $-.241^{* *}$ \\
\hline & Sig. (2-tailed) & .000 & & .000 & .000 \\
\hline & $\mathrm{N}$ & 444 & 446 & 446 & 435 \\
\hline \multirow{3}{*}{ Doing best in studying English } & Pearson Correlation & $.489^{* *}$ & $.392^{* *}$ & 1 & $-.178^{* *}$ \\
\hline & Sig. (2-tailed) & .000 & .000 & & .000 \\
\hline & $\mathrm{N}$ & 445 & 446 & 447 & 436 \\
\hline \multirow[t]{3}{*}{ School Location } & Pearson Correlation & $-.103^{*}$ & $-.241^{* *}$ & $-.178^{* *}$ & 1 \\
\hline & Sig. (2-tailed) & .032 & .000 & .000 & \\
\hline & $\mathrm{N}$ & 434 & 435 & 436 & 436 \\
\hline
\end{tabular}

**. Correlation is significant at the 0.01 level (2-tailed).

*. Correlation is significant at the 0.05 level (2-tailed).

This table also shows a significant correlation $(p=.032)$ between students' willingness to learn English very hard and their school locations. However, as the relationship is negative ( $r=-.103)$, it may mean that the more rural the location of the school, the less supports students can receive, leading to their low motivation and achievement in English. 
The third correlation between motivation and parental education is described in Table 5.

Table 5 shows a more significant correlation between students' motivation and father, not the mother's educational background. Despite gender difference, this indicates the importance of parental support in English learning.

The fourth correlation between motivation and family English skills, as described in Table 6.

Table 5. Correlation between motivation and parental education

\begin{tabular}{|c|c|c|c|c|c|c|}
\hline & & $\begin{array}{l}\text { Studying } \\
\text { hard }\end{array}$ & $\begin{array}{l}\text { Spending } \\
\text { time }\end{array}$ & $\begin{array}{c}\text { Doing } \\
\text { best }\end{array}$ & $\begin{array}{c}\text { Father's } \\
\text { Occupation }\end{array}$ & $\begin{array}{c}\text { Mother's } \\
\text { Occupation }\end{array}$ \\
\hline \multirow[t]{3}{*}{$\begin{array}{l}\text { Studying English very } \\
\text { hard }\end{array}$} & $\begin{array}{l}\text { Pearson } \\
\text { Correlation }\end{array}$ & 1 & $.527^{* * *}$ & $.489^{* * *}$ & .076 & .047 \\
\hline & Sig. (2-tailed) & & .000 & .000 & .113 & .329 \\
\hline & $\mathrm{N}$ & 445 & 444 & 445 & 440 & 441 \\
\hline \multirow[t]{3}{*}{$\begin{array}{l}\text { Spending time for studying } \\
\text { English }\end{array}$} & $\begin{array}{l}\text { Pearson } \\
\text { Correlation }\end{array}$ & $.527^{* *}$ & 1 & $.392^{* *}$ & $.186^{* *}$ & .048 \\
\hline & Sig. (2-tailed) & .000 & & .000 & .000 & .309 \\
\hline & $\mathrm{N}$ & 444 & 446 & 446 & 441 & 442 \\
\hline \multirow[t]{3}{*}{$\begin{array}{l}\text { Doing best in studying } \\
\text { English }\end{array}$} & $\begin{array}{l}\text { Pearson } \\
\text { Correlation }\end{array}$ & $.489^{* *}$ & $.392^{* *}$ & 1 & -.017 & .081 \\
\hline & Sig. (2-tailed) & .000 & .000 & & .726 & .088 \\
\hline & $\mathrm{N}$ & 445 & 446 & 447 & 442 & 443 \\
\hline \multirow[t]{3}{*}{ Father's Occupation } & $\begin{array}{l}\text { Pearson } \\
\text { Correlation }\end{array}$ & .076 & $.186^{* *}$ & -.017 & 1 & $.219^{* *}$ \\
\hline & Sig. (2-tailed) & .113 & .000 & .726 & & .000 \\
\hline & $\mathrm{N}$ & 440 & 441 & 442 & 442 & 438 \\
\hline \multirow[t]{3}{*}{ Mother's Occupation } & $\begin{array}{l}\text { Pearson } \\
\text { Correlation }\end{array}$ & .047 & .048 & .081 & $.219^{* * *}$ & 1 \\
\hline & Sig. (2-tailed) & .329 & .309 & .088 & .000 & \\
\hline & $\mathrm{N}$ & 441 & 442 & 443 & 438 & 443 \\
\hline
\end{tabular}

**. Correlation is significant at the 0.01 level (2-tailed).

Table 6. Correlations between motivation and English course

\begin{tabular}{|c|c|c|c|c|c|}
\hline & & Studying hard & Spending time & Doing best & English Course Taken \\
\hline \multirow[t]{3}{*}{ S tudying English very hard } & Pearson Correlation & 1 & $.527^{* *}$ & $.489^{* * *}$ & $.119^{*}$ \\
\hline & Sig. (2-tailed) & & .000 & .000 & .012 \\
\hline & $\mathrm{N}$ & 445 & 444 & 445 & 444 \\
\hline \multirow{3}{*}{$\begin{array}{l}\text { Spending time for studying } \\
\text { English }\end{array}$} & Pearson Correlation & $.527^{* *}$ & 1 & $.392^{* *}$ & $.161^{* *}$ \\
\hline & Sig. (2-tailed) & .000 & & .000 & .001 \\
\hline & $\mathrm{N}$ & 444 & 446 & 446 & 445 \\
\hline \multirow[t]{3}{*}{ Doing best in studying English } & Pearson Correlation & $.489^{* *}$ & $.392^{* *}$ & 1 & $.126^{* *}$ \\
\hline & Sig. (2-tailed) & .000 & .000 & & .008 \\
\hline & $\mathrm{N}$ & 445 & 446 & 447 & 446 \\
\hline \multirow[t]{3}{*}{ English Course Taken } & Pearson Correlation & $.119^{*}$ & $.161^{* * *}$ & $.126^{* *}$ & 1 \\
\hline & Sig. (2-tailed) & .012 & .001 & .008 & \\
\hline & $\mathrm{N}$ & 444 & 445 & 446 & 446 \\
\hline
\end{tabular}

\footnotetext{
**. Correlation is significant at the 0.01 level (2-tailed).

*. Correlation is significant at the 0.05 level (2-tailed).
}

Similarly, Table 6 shows a significant correlation between students' motivation and the English language skills of their family members. The higher the English skills of their family members, the higher their motivation to learn this language.

The last correlation is between motivation and parental jobs, as explained in Table 7. It also shows a significant relationship between learners' motivation which includes studying hard, spending time, and doing best in English learning and parental occupation. This means that the higher the SES of parents, the higher the motivation of children in learning English. 
Table 7 Correlation between motivation and parental jobs

\begin{tabular}{|c|c|c|c|c|c|c|}
\hline & & $\begin{array}{c}\text { Studying } \\
\text { hard }\end{array}$ & $\begin{array}{c}\text { Spending } \\
\text { time }\end{array}$ & $\begin{array}{c}\text { Doing } \\
\text { best }\end{array}$ & $\begin{array}{c}\text { Father's } \\
\text { Occupation }\end{array}$ & $\begin{array}{c}\text { Mother's } \\
\text { Occupation }\end{array}$ \\
\hline \multirow[t]{3}{*}{ Father's Occupation } & $\begin{array}{l}\text { Pearson } \\
\text { Correlation }\end{array}$ & .076 & $.186^{* *}$ & -.017 & 1 & $.219^{* *}$ \\
\hline & Sig. (2-tailed) & .113 & .000 & .726 & & .000 \\
\hline & $\mathrm{N}$ & 440 & 441 & 442 & 442 & 438 \\
\hline \multirow[t]{3}{*}{$\begin{array}{l}\text { Mother's } \\
\text { Occupation }\end{array}$} & $\begin{array}{l}\text { Pearson } \\
\text { Correlation }\end{array}$ & .047 & .048 & .081 & $.219^{* *}$ & 1 \\
\hline & Sig. (2-tailed) & .329 & .309 & .088 & .000 & \\
\hline & $\mathrm{N}$ & 441 & 442 & 443 & 438 & 443 \\
\hline
\end{tabular}

**. Correlation is significant at the 0.01 level (2-tailed).

\section{Interviews and document analysis}

In addition to questionnaire results, data in this study were also generated from interviews with 15 teachers of the participating students. The interview questions include teachers' educational background, classroom learning condition, and students' grading/marking process. Meanwhile, the document examined in this study is the students' test scores. The results of these interviews serve to confirm the results of the students' questionnaire.

Based on the interviews, almost all teachers believe that most students demonstrate low motivation to learn English. The majority of students, regardless of their school geographical locations, do not put enough efforts to learn English, feel reluctant to participate in classroom discussion and homework completion. This fact is in line with what the questionnaire results show about intended efforts for learning, which is only medium (4.00 of 06.00). A male teacher reveals, Most of my students, you know, are not enthusiastic about learning English. Maybe because our school is in a small city. Our students do not feel it important to learn English. They may think they will not use it outside their classrooms. (Teacher \#1)

Another female teacher also showed her concern about the decreasing interests of her students during the learning process in the classroom. She points out, I don't know why my students are not really interested in my English classroom. I have to force them to learn. For example, if I give them homework, most of them do not complete it. I have to ask them again and again to complete the homework. (Teacher \#2)

Another teacher complained about students' low commitment to personal development. For English language skill development, they seem to have weak willingness to develop their English speaking as part of their professionalskills. One female teacher notes, With another English teacher, we organize an English conversation club to improve students' speaking skill. Some students do not come to the program. When we asked, they said, they are shy to come because their English is not good enough. (Teacher \#3)

Some other teachers are also worried about students' English proficiency. In general, the overall score of English is unsatisfactory, scoring 6 or less out of 10. The average score is often lower for nonfavourite or prestigious schools. As evidence to this claim, one female teacher showed the result of Try Out (TO) administered by a Private Tutoring Agency in her town, showing the highest real score of 4-5 out of 10 . Despite this low mark, however, to secure the school performance, teachers have to mark up their students' English scores to pass the minimum passing grade. One teacher reports,

Look at this TO real result. The maximum is only 45 . We are forced by the school principal and district education office to mark up our students' rapports. Their English language skill is not actually as good as what their rapports show. Only a few students who really have good English skills. Most students, especially at non-favourite schools, have marked up rapport results. (Teacher \#4)

These interview results reveal some phenomenon in relation to students' motivation and achievement; students' low motivation and enthusias m for learning, unconducive classroom situation, and unsatisfactory academic achievement.

\section{DISCUSSION}

This section relates the findings with some relevant theories of English learning motivation, findings of the previous studies, as well as draw some interesting novel points this study has identified in relation to English learning motivation among the participating Indonesian SHS students.

First, both tables 1 and 2 of overall questionnaire data show that all participating students have practised and acquired all necessary individual and social aspects of learning motivation. Of these figures, some individual aspects have scores 5.00 of 6.00 scale in three constructs; ideal self (statements 7,8, 10 and 11), international posture (statements 18-20) and instrumentality (statements 24-26). As for ideal self, most students highly agree that they need to have good English language skills, and be able to effectively communicate with people from overseas. Meanwhile, as for international posture, most participating students believe that they want to learn English to be able to communicate with international people. Finally, as for instrumentality, they believe that English is necessary for their future careers, including university enrollment. 
Similarly, some social aspects of motivation have scores 5.00 of 6.00 (family, teachers, and out of school). Most students believe that family strongly supports them to learn English well, and teachers have a strong role and motivate to help English learning. Meanwhile, they also like learning English outside school through song, films, and magazines. These findings support previous studies which emphasize the importance of individual and social aspects of motivation among Asian English learners such as teachers, peers, family members, education system, and cooperative learning (Alhodiry, 2016; Mahmoodi et al., 2014; Tanaka, 2017; Vatankhah \& Tanbakooei, 2014; Zhou, 2012; Zubairi \& Sarudin, 2009), including in Indonesian context (Lamb, 2004, 2007, 2013; Marcelino, 2008; Musthafa, 2010). Nevertheless, in relation to the poor learning enthusiasm and low English proficiency and achievement, this level of English learning motivation is not really satisfactory, considering the importance of English in the future life of the participating students.

Next, besides having satisfactory motivational levels, 4.00-5.00 (medium to high), participating students have also acknowledged the importance of intended efforts, ideal and ought-to selves in English learning. Within limited supporting facilities, particularly among students in remote schools, the participating students have a good practice of both instrumental and integrative motivation (Deci \& Ryan, 1985; Dörnyei, 1994; Lamb, 2004, 2007, 2013). In addition, they also have a good comprehension of the importance of social supports from peers, teachers, and family members in improving their English proficiency. In its modest level, the participating students have embraced what Harvey (2017) calls as the ideology of learning a foreign language (p. 70) which can 'instigate and sustain' their English learning process (Schunk, Pintrich, \& Meece, 2008, p. 4) or underlie their English learning behaviors (Guay et al., 2010). However, borrowing Norton's (2000, 2013) term, having associated themselves as English language learners, students have not invested time and energy to learn the language. In other words, their confirmation for groupspecific or social identity as English language learners (Dörnyei, 1994; Norton, 2013) does not guaranatee their investment in learning English as indicated by low motivation in English learning at schools and poor English proficiency.

Again, it is interesting to note that although teachers' influence is rather high (4.67), the classroom learning experience is low (4.00) supported by low peer's influence (4.00). This means that the learning situation in the classroom is not conducive or stimulating, whereas, in fact, it is an important aspect of learning motivation, together with language and learner (Dörnyei, 1994). It is believed that when learners feel socially motivated to learn English as they foresee its benefits, they will invest their time and energy to learn English (Norton, 2000, 2013). This consequencial investment in English learning cannot, unfortunately, be clearly identified from the participating students in this study. Therefore, to provide more stimulating classroom learning situation, teachers need to improve their competency by taking part in some professional training development. They need to develop their knowledge and practice of cooperative learning by developing learners' positive interdependence, group processing and social skills (Johnson \& Johnson, 1994) through a group-based project called Group-Directed Motivational Currents (Dörnyei, Henry, \& Muir, 2016). This project can direct and energize the motivational currents of students to achieve their goals, orientation, needs and aspiration (p. xi). In addition to English learning, this project also enables students to learn leadership, conflict management, and decision making, necessary skills for students in their future life.

Furthermore, it is also exciting to find out that outside school learning experience is stronger (4.25) than that of inside the school. For many students, as some studies have indicated (Lamb, 2007; Supriyanti, 2012; Yulia, 2013), English course outside the school is more attractive than the learning process at school due to effective learning method, more supporting facilities and innovative learning materials. As supporting evidence, teachers' interview reveals how students often feel less enthusiastic in the classroom. In this case, students may need some breakthrough in classroom management and teaching methodology, which can boost their motivation. Here, teachers need more professional development on how to make their learning process or situation more fun for the students. As Dörnyei (1994) has pointed out, learning situation is another important aspect of motivation, together with learner and language. To make learning experience in the classroom more attractive to students, teachers need to keep updating their teaching methodology and other aspects of professionalism to accommodate the increasing needs of students for English. As the case with the participating English language teachers in this study, they need to modify the learning materials prescribed by the government with their owns so that students feel more motivated to learn and develop their English language competence. To increase learning interest and support comprehension, along with issues of learning autonomy and contextual learning, for example, learning materials of narratives should be contextualized by employing local narrative texts which are derived from students' cultural backgrounds such as Danau Toba, Sangkuriang and Joko Tingkir, in addition to those of English culture such as Snow White, Sleeping Beauty and The Goldilock (Muslim et al., 2009). As for millennial learners, teachers need to integrate the use of technology in their teaching and learning. With this innovation, students feel more culturally attached and teachnologically accommodated so that they can increase their enthusiasm in learning English.

Finally, within its limited level, the aforementioned figures about individual and social aspects of English learning indicate both participants' integrative and instrumental aspects of motivation 
towards English learning as previous studies have shown (Carrió-Pastor \& Mestre, 2014; Iwaniec, 2014; Khajehpour \& Ghazvinia, 2011). Due to their low English proficiency, however, this positive motivation still needs significant support. The fact that some students, particularly at urban schools, have taken English courses outside schools, shows that classroom teaching experience is not that interesting, leading to their low motivation to learn English in the classrooms. The participating SHS students need more external triggers or supports so that they are commited to invest time and energy to improve their English proficiency. Since out-of-school English course is still a luxury for most Indonesian students, as Dörnyei, Henry, and Muir (2016) have identified in their study, Indonesian students need a systemic booster which can improve their group motivation in the classroom through GroupDirected Motivational Currents (G-DMC). Required by the national English curriculum 2013 in Indonesia, this project-based learning (PBL) enables students to work together, directed by well-trained professional teachers to increase their learning enthusiasim in the classroom so that they can sustain their learning and have good English proficiency necessary for their current studies and future dreams as global citizens of ASEAN and the world. Supporting some previous studies on cooperative learning (Johnson \& Johnson, 1994; Olsen \& Kagan, 1992), and with the aims to achieve certain English learning goals (language skills) and rewards, various interactions in this project-based learning such as faceto-face and online for millenials, enable learners to have different authentic roles so that they can develop their positive interdependence, individual accountability, group processing and social skills. Not only is this project expected to increase the integrative and instrumental motivation of the participating SHS students but also encourage them to invest in learning so that they can achieve the expected English proficiency.

\section{CONCLUSIONS}

Based on the abovementioned discussion, this study concludes some points. First, most participating students, regardless of their schooling backgrounds (general, vocational and religion-affiliated), have indicated both integrative and instrumental motivation to learn English. This international language is considered important for their future careers so that they have made some efforts to learn English and have earned positive social supports from their peers, teachers and parents. However, this instrumental and integrative aspects of motivation do not always lead to high investment and commitment. Having believed that English is necessary for their future careers, participating students do not show high investment to learn English as demonstrated by low enthusiasm in the classroom interaction and poor English proficiency. This low investment may be the result of teachers' low professionalism so that they cannot trigger students to invest in learning English. To anticipate this challenge, students need external supports like more attractive classroom cooperative learning in which students have more autonomy to learn with their peers. In this case, Group-Directed Motivational Currents (G-DMC) is considered necessary to apply to increase students' motivation and investment for English learning. Not only does it serve as an innovative way of learning but also a millennial way of social engagement.

Finally, for more conclusive findings, the study also provides some suggestions. First, in order to yield more convincing arguments, future study should include observations so that more real classroom discourse can be portrayed. Second, the study should also compare the participants with those from other provinces of Indonesia with different socio-cultural backgrounds so that more comprehensive findings on Indonesian students' English learning motivation and investment can be identified more clearly.

\section{ACKNOWLEDGMENTS}

The researchers thank the participating teachers and students in five districts of West Java province in this study funded by the Center for Research and Community Engagement, Universitas Pendidikan Indonesia, the year 2017.

\section{REFERENCES}

Alhodiry, A. A. (2016). The Libyan EFL Teachers' role in developing students' motivation. ProcediaSocial and Behavioral Sciences, 232, 83-89. doi: 10.1016/j.sbspro.2016.10.020

Amold, J. (2000). Affect in language learning. Beijing: Beijing Foreign language Teaching and Research Press.

Beckett, G. H., \& Slater, T. (2005). The project framework: A tool for language, content, and skills integration. ELT Journal, 59(2), 108-116. doi: 10.1093/eltj/cci024

Carrió-Pastor, M. L. \& Mestre, E. M. M. (2014). Motivation in second language acquisition. Procedia-Social and Behavioral Sciences, 116 , 240 - 244. doi: 10.1016/j.sbs pro.2014.01.201

Carrió-Pastor, M. L., \& Skorczynska, H. (2015). Collaborative learning and communication technologies in teaching business English. Procedia-Social and Behavioural Science, 178, 32-37. doi: 10.1016/j.sbspro.2015.03.142

Çelik, S., Aytin, K., \& Bayram, E. (2013). Implementing cooperative learning in the language classroom: Opinions of Turkish teachers. Procedia - Social and Behavioural Science, 70, 1852-1859. doi: 10.1016/j.sbspro.2013.01.263

Creswell, J. W. (2014). Research design: qualitative, quantitative, and mixed method approaches. Los Angeles: SAGE.

Crookes, G. \& Schmidt R. W. (1991). Motivation: Reopening the research agenda. Language 
Learning , 41(4), 469-512. doi: 10.1111/j.14671770.1991.tb00690.x

Dörnyei, Z. (1994). Motivation and motivating in the foreign language classroom. The Modern Language Journal,78(3), pp. 273-284. doi: 10.1111/j.1540-4781.1994.tb02042.x

Dörnyei, Z. (1997). Psychological process in cooperative language learning: Group dynamics and motivation. Modern Language Journal, 81(4), 482-492. doi: 10.1111/j.15404781.1997.tb05515.x

Dörnyei, Z., Henry, A. \& Muir, C. (2016). Motivational currents in language learning: Frameworks for focused intervention. New York: Routledge.

Ellis, R. (1994). The study of second language acquisition. Oxford: Oxford University Press.

Guay, F., Chanal, J., Ratelle, C. F., Marsh, H. W., Larose, S., \& Boivin, M. (2010). Intrinsic, identified, and controlled types of motivation for schoolsubjects in young elementary school children. British Journal of Educational Psychology, 80(4), 711-735. doi: 10.1348/000709910x499084

Hamied, F.A. (2017). Research methods: A guide for first-time researchers. Bandung: UPI Press.

Harvey, L. (2017). Language learning motivation as ideological becoming. System, 65, 69-77. doi: 10.1016/j.system.2016.12.009

Iwaniec, J. (2014). Motivation of pupils from southern Poland to learn English. System, 45, 67-78. doi: 10.1016/j.sys tem.2014.05.003

Johnson, D.W. \& Johnson, R. T. (1994). Leading the cooperative school ( $2^{\text {nd }} \mathrm{Ed}$.). Edina, $\mathrm{MN}$ : Interaction Book Co.

Kagan, S. (1994). Cooperative learning. San Clemente, CA: Kagan Publishing.

Khajehpour, M. \& Ghazvinia, S. D. (2011). Attitudes and Motivation in learning English as Second Language in high schoolstudents. Procedia-Social and Behavioral Sciences, 15, 1209-1213. doi: 10.1016/j.sbspro.2011.03.264

Kormos, J. \& Kiddle, T. (2013). The role of socioeconomic factors in motivation to learn English as a foreign language: The case of Chile. System, 41(2), 399-412. doi: 10.1016/j.s ystem.2013.03.006

Lamb, M. (2004). Integrative motivation in globalizing world. System, 32(1), 3-19. doi: 10.1016/j.system.2003.04.002

Lamb, M. (2007). The impact of school on EFL learning motivation: An Indonesian case study. TESOL Quarterly, 41(4), 757-780. doi: 10.1002/j.15457249.2007.tb00102.x

Lamb, M. (2013) "Your mum and dad can't teach you!': Constraints on agency among rural learners of English in Indonesia', Journal of Multilingual and Multicultural Development, 34(1), 14-29. doi: 10.1080/01434632.2012.697467

Mahmoodi, M. H., Kalantari, B., \& Ghaslani, R. (2014). Self-regulated learning (SRL), motivation and language achievement of Iranian EFL learners.
Procedia-Social and Behavioral Sciences, 98, 1062-1068. doi: 10.1016/j.sbspro.2014.03.517

Marcelino, M. (2008). English language teaching in Indonesia: A continuous challenge in education and cultural diversity. TEFLIN Journal, 19(1), $57-$ 69.

Ministry of Education and Culture. (2013). English language curriculum for SMA/SMK/MA. Jakarta.

Muslim, A. B., Nafisah, N., \& Damayanti, I. L. (2009). Locality and self identity: Local story inclusion in Indonesian English text-books. A conference proceeding at the International Seminar on Language and Culture: Creating and Fostering Global Communities, School of Language Studies and Linguistics, Faculty of Social Sciences and Humanities, Malaysia National University.

Muslim, A. B. (2017). Heritage narratives, motivation to learn English and the formation of national identity: An Indonesian perspective. Journal of the Asia TEFL, 14(3), 414-429. doi: 10.18823/asiatefl.2017.14.3.3.414

Musthafa, B. (2010). Teaching English to Young Learners in Indonesia: Essential Requirements. Educationist, 4(2), 120-125.

Norton, B. (2000). Identity and language learning: Gender, ethnicity and educational change. New York: Longman.

Norton, B. (2013). Identity and language learning: Extending the conversation ( $2^{\text {nd }}$ ed.). Toronto: Multilingual Matters.

Olsen, R. E. W. B. \& Kagan, S. (1992). About cooperative learning. In C. Kessler (Ed.), Cooperative language learning: A teacher's resource book (pp. 1-30). Englewood Cliffs, NJ: Prentice Hall.

Richards, J. C. \& Rodgers, T. S. (2001). Approaches and methods in language teaching. Boston, MA: Cambridge University Press.

Sayer, P. (2018). Does English really open doors? Social class and English teaching in public primary schools in Mexico. System, 73, 58-70. doi: 10.1016/j.system.2017.11.006

Schunk, D.H., Pintrich, P.R. \& Meece, J.L. (2008). Motivation in education: Theory, research, and application ( $3^{\text {rd }}$ ed.). New Jersey: Pearson Merrill Prentice Hall.

Stapa, M. A., Ibrahim, M. \& Yusoff, A. (2015). Engaging vocational college students through blended learning: Improving class attendance and participation, Procedia - Social and Behavioral Sciences, 204, 127-135. doi: 10.1016/j.sbs pro.2015.08.125

Supriyanti, N. (2012). Challenges in Providing Trainings for English Teachers of Elementary Schools. Journal of Education and Learning, 6(3), 161-166. doi: 10.11591/edulearn.v 6i3.159

Tanaka, M. (2017). Examining EFL vocabulary learning motivation in a demotivating learning environment. System, 65, 130-138. doi: 10.1016/j.system.2017.01.010 
Taylor, D. M., Meynard, R. \& Rheault, E. (1977). Threat to ethnic identity and second-language learning. In H. Giles (Ed.), Language, ethnicity and intergroup relations (pp. 99-118). London \& NY: Academic Press.

Vatankhah, M. \& Tanbakooei, N. (2014). The role of social support on intrinsic and extrinsic motivation among Iranian EFL Learners. Procedia-Social and Behavioral Sciences, 98, 1912-1918. doi: 10.1016/j.sbs pro.2014.03.622

Waterworth, P. (2016). Teaching English in ASEAN: The voices of English teachers in ASEAN nations.
Indonesian Journal of Applied Linguistics, 5(2), 541-166. doi: 10.17509/ijal.v5i2.1340

Yulia, Y. (2013). Teaching challenges in Indonesia: Motivating students and teachers' class room language. Indonesian Journal of Applied Linguistics, 3(1), 1-16. doi: 10.17509/ijal.v3i1.186

Zhou, H. (2014). Enhancing non-English majors' EFL motivation through Cooperative Learning. Procedia Environmental Sciences, 12, 1317-1323. doi: 10.1016/j.proenv.2012.01.428

Zubairi, A. M \& Sarudin, I. (2009). Motivation to learn a foreign language in Malaysia. GEMA Online Journal of Language Studies, 9(2), 73-87. 


\section{APPENDICES}

Appendix 1

Individual motivation of English learners

\begin{tabular}{|c|c|c|c|c|c|c|c|}
\hline Construct & Indocators of motivation & 1 & 2 & 3 & 4 & 5 & 6 \\
\hline \multicolumn{2}{|c|}{ Individual motivation } & & & & & & \\
\hline \multirow[t]{3}{*}{ Intended efforts } & I work hard to learn English, & & & & & & \\
\hline & I don't mind spending much time learning English, & & & & & & \\
\hline & I am doing my best to learn English. & & & & & & \\
\hline \multirow[t]{7}{*}{ Ideal self } & I work hard to learn English outside school & & & & & & \\
\hline & Many of my future works relate to English, & & & & & & \\
\hline & I want to be an Indonesian who has good English language skill & & & & & & \\
\hline & I often imagine of becoming someone with good English language skill & & & & & & \\
\hline & $\begin{array}{l}\text { It is easy for me to imagine myself as someone with good English } \\
\text { language skill }\end{array}$ & & & & & & \\
\hline & $\begin{array}{l}\text { I imagine that one day I can communicate in English with young } \\
\text { people from other countries }\end{array}$ & & & & & & \\
\hline & $\begin{array}{l}\text { One of my future dream is that I can communicate effectively in } \\
\text { English. }\end{array}$ & & & & & & \\
\hline \multirow[t]{6}{*}{ Ought to self } & I learn English so that I don't fail at school & & & & & & \\
\hline & All young Indonesians are required to learn English seriously & & & & & & \\
\hline & To be a good student, I have to poses good English language skill & & & & & & \\
\hline & Learning English language is important as people think so & & & & & & \\
\hline & $\begin{array}{l}\text { Adults who cannot speak English well are often considered foolish or } \\
\text { less educated }\end{array}$ & & & & & & \\
\hline & $\begin{array}{l}\text { Other people (teachers, parents, and friends) will feel shy/disappointed } \\
\text { if I cannot speak English well. }\end{array}$ & & & & & & \\
\hline \multirow[t]{7}{*}{$\begin{array}{l}\text { International } \\
\text { posture }\end{array}$} & $\begin{array}{l}\text { I learn English so that I can communicate with people from other } \\
\text { countries }\end{array}$ & & & & & & \\
\hline & English is required in today's international communication & & & & & & \\
\hline & $\begin{array}{l}\text { English is considered an important means of international } \\
\text { communication }\end{array}$ & & & & & & \\
\hline & English is considered the most important language in the world & & & & & & \\
\hline & English is really necessary in today's international communication & & & & & & \\
\hline & English is considered the most important language in the world & & & & & & \\
\hline & I am interested in following international events. & & & & & & \\
\hline \multirow[t]{4}{*}{ Instrumentality } & English language skill is necessary to support my hobby & & & & & & \\
\hline & English is also required to support my study success & & & & & & \\
\hline & My English language helps me get job more easily & & & & & & \\
\hline & $\begin{array}{l}\text { My English language helps my university enrollment after completing } \\
\text { high school }\end{array}$ & & & & & & \\
\hline
\end{tabular}




\section{Appendix 2 \\ Social motivation of English learning}

\begin{tabular}{|c|c|c|c|c|c|c|c|}
\hline Construct & Indocators of motivation & 1 & 2 & 3 & 4 & 5 & 6 \\
\hline \multicolumn{8}{|l|}{ Social motivation } \\
\hline \multirow[t]{4}{*}{ Family influence } & My family members have negative attitudes towards English & & & & & & \\
\hline & $\begin{array}{l}\text { To become an educated person, my family requires me to learn } \\
\text { English }\end{array}$ & & & & & & \\
\hline & Family supports me to learn English well & & & & & & \\
\hline & My family consider it important that I have good English skill. & & & & & & \\
\hline \multirow[t]{3}{*}{ Teachers' influence } & Teacher's role really helps my English learning & & & & & & \\
\hline & At least, I have a teacher who can motivate me to learn English & & & & & & \\
\hline & All teachers support me to learn English seriously. & & & & & & \\
\hline \multirow[t]{5}{*}{ Peer's influence } & Most of my peers have positive attitude towards English & & & & & & \\
\hline & Most of my peers support me to learn English & & & & & & \\
\hline & Most of my peers like English subject. & & & & & & \\
\hline & I have a close friend who supports me to learn English & & & & & & \\
\hline & $\begin{array}{l}\text { At least, I have a close friend who motivates me to have } \\
\text { positive attitude towards English. }\end{array}$ & & & & & & \\
\hline \multirow{4}{*}{$\begin{array}{l}\text { Learning experience at } \\
\text { school }\end{array}$} & I like the English learning environment at school & & & & & & \\
\hline & I never feel bored of studying English at school & & & & & & \\
\hline & I enjoy learning English at school. & & & & & & \\
\hline & My English teacher makes learning more fun. & & & & & & \\
\hline \multirow[t]{4}{*}{$\begin{array}{l}\text { Learning experience } \\
\text { outside school }\end{array}$} & $\begin{array}{l}\text { On my own, I often look up for new word meanings outside the } \\
\text { classroom. }\end{array}$ & & & & & & \\
\hline & $\begin{array}{l}\text { I like learning English outside school through song, films, and } \\
\text { magazines, }\end{array}$ & & & & & & \\
\hline & I like reading, watching, and listening activities in English. & & & & & & \\
\hline & I also like learning English at home. & & & & & & \\
\hline \multirow[t]{4}{*}{ Language anxiety } & $\begin{array}{l}\text { I often feel nervous when speaking with English native } \\
\text { speakers. }\end{array}$ & & & & & & \\
\hline & Speaking English makes me nervous. & & & & & & \\
\hline & $\begin{array}{l}\text { I am worried that English native speakers will consider my } \\
\text { English weird. }\end{array}$ & & & & & & \\
\hline & $\begin{array}{l}\text { I often feel nervous when asked to speak in front of the } \\
\text { classroom. }\end{array}$ & & & & & & \\
\hline
\end{tabular}

Appendix 3

Teacher's Interview Guide

1. How is yourstudents' motivation in English learning?

2. Do they show enthusiasm in learning? How do you know it?

3. How is yourstudents' English achievement? Is it satisfactory enough? Why?

4. Do yourstudents take part in out-of-schoolEnglish learning? why?

5. Do you have the plan to improve your students' motivation in learning English? What?

6. Do you involve your students in a group-based project? What are they?

7. Are you familiar with Group-Directed Motivational Currents (G-DMC)? What is it?

8. Are you interested in involving your students in G-DMC activities? How? 